\title{
KETERKAITAN STRATEGI ORIENTASI DAN KINERJA PERUSAHAAN TERHADAP PENGARUH TEKNOLOGI INFORMASI
}

\author{
Nama : Adra Elviona R. \\ NRP / KP : 130119056 /A \\ Email : adraelvionaa@gmail.com
}

Adanya suatu perubahan technology information ini membuat adanya suatu peluang dalam kinerja perusahaan yaitu dapat mengembangkan segala aspek kemampuannya di berbagai bidang termasuk pemasaran dan pengembangan produknya. Sehingga dalam hal ini dapat menjangkau keuntungan yang cukup besar pada pelaksanaan strategy orientation suatu perusahaan di dunia pemasaran langsung yang ini juga dapat meraup pelanggan dengan informasi pasar yang lebih luas.

Hal ini juga dilanjutkan pada penelitian yang mengusulkan technology turbulence (TT) yang dimana sebagai faktor kontingensi utama yang berfokus pada strategy orientation (SO) sebagai determinan utama kinerja perusahaan / firm Performances (Pratono, 2016). Dengan adanya technology turbulence (TT) ini akan membuat perusahaan dan bisnis - bisnis mengalami pelonjakan yang bisa dibilang cukup dinamis pada skala UKM dengan adanya pemanfaatan sebuah teknologi. Maka dari itu disini strategy orientation (SO) memiliki keterkaitan terhadap FP dan TT yang memiliki fungsi sebagai pendorong pada orientasi pasar responsif dan pasar proaktif, serta sebagai kunci terbukanya peluang pasar yang lebih luas dan bisa diterapkan untuk menjalankan bisnis dan perusahaan.

\section{Bibliography}

Pratono, A. (2016). Strategic orientation and information technological turbulence: Contingency perspective in SMEs. Business Process Management Journal, 22(2), 368-382. 